\title{
Adaptation of Mertasari Kite Shop's Economic Activities During the Covid-19 Pandemic
}

\author{
Ni Wayan Ayu Santi ${ }^{1{ }^{*}}$ Luh Indrayani ${ }^{1}$ Lucy Sri Musmini ${ }^{1}$ \\ ${ }^{1}$ Department of Economics and Accounting, Universitas Pendidikan Ganesha, Singaraja, Indonesia \\ *Corresponding author. Email: ayu.santi@undiksha.ac.id
}

\begin{abstract}
The purpose of this study was to determine the adaptation of economic activities carried out by Mertasari Kite Shop during the covid-19 pandemic. The research method used descriptive qualitative methods. The techniques used in collecting data in this study were observation and interviews and were analyzed in three stages, namely data reduction, data presentation, and conclusion drawing. The results of this study obtained data that there was an adaptation of economic activities carried out by Mertasari Kite Shop during the covid-19 pandemic, among others in (1) production activities: making new designs, product diversification, (2) distribution activities: maximizing product sales, and promotions. (3) consumption activities: limiting employee working hours.
\end{abstract}

Keywords: Adaptation, economic activities and Covid-19.

\section{INTRODUCTION}

At the beginning of 2020 there was the spread of a virus known as Corona virus disease (Covid-19. Various sectors of life were affected, even the sector that suffered a fairly heavy blow was tourism. Lockdown policies in several countries, PSBB (Large-Scale Social Restrictions) and PPKM (Enforcement of Restrictions on Community Activities) in various parts of Indonesia have stopped traveling and tourism activities have stagnated [1]. The government and all levels of society are still trying to contain the spread of covid-19. All aspects of life have changed due to the covid-19 pandemic. People are forced to keep a distance from one individual to another in order to prevent wider transmission. Therefore, all human activities are trying to be transferred to the network (online). Learning activities, activities of goods or services of the companies and government activities are also trying to be transferred to online. Only activities that are serviceoriented are still being carried out outside the network provided that they must be equipped with complete health equipment or known as health protocols in accordance with government policies. Based on this, the government and all levels of society are trying to adapt or adjust all activities during this pandemic.

Adaptation is an act of adjusting to the surrounding environment. Adaptation is one of the interesting research objects to be studied at this time because of a phenomenon or event that suddenly has changed all community activities without any prior planning. So that it is sought so that the community is willing to adapt all their activities to new life habits in order to prevent the wider spread of Covid-19. The Covid-19 pandemic is a situation that makes people forced or suddenly adapt to avoid the Covid-19 virus. The activity of gathering with many people directly began to be avoided so that it had an impact on various community activities in earning income, one of which was in the tourism sector as expressed by [2]. This of course greatly reduces population mobility which greatly impacts the economic performance of a region such as the tourism sector. The tourism sector in Indonesia is one sector that is being sought to be considered so that it is able to attract foreign tourists, but due to the covid-19 pandemic, it has been delayed. Over time, it has been almost a year since this pandemic has lasted, people who work or their source of income in the tourism sector always innovates to provide all excellent services safely and healthily so as to avoid the covid-19 virus. Likewise in Bali, Bali is one of the islands that is well known throughout the world so that the main source of income for Balinese people is from the tourism sector.

The tourism sector is the leading sector on the island of Bali, known as the Island of the Gods or the Island of a Thousand Temples, so that foreign or domestic people always want to travel to Bali again. Because of this, the Balinese people rely heavily on the tourism sector. 
However, with the covid-19 pandemic, all walks of life are forced to adapt by looking for other sources of income. Some Balinese people are aware that the tourism sector must make changes which adapt to the current situation so that the local government has been circumventing it with various policies, such as traveling with strict procedures, before coming to Bali, they must show a certificate of negative swab/pcr results and show their vaccine card. As stated by [3] the tourism sector will prioritize the application of health protocol standards and safety standards that are deemed adequate to maintain the comfort of tourists visiting Bali. This is done to reduce the spread of the Covid-19 virus so that the economy in Bali is able to increase.

Based on report data [4] Bali's economy in the second quarter at the end of August 2021 grew positively, improving compared to the previous quarter which is contracted. Bali's economy grew by $2.83 \%$ (yoy), better than the previous quarter, It is $9.81 \%$ (yoy). The improvement in Bali's economic performance in the second quarter of 2021 was also driven by the easing of the PPKM policy in the second quarter of 2021 accompanied by the implementation of health protocols that provide room for increased domestic tourism activities, which is also supported by the implementation of an on-track vaccination program. Increasing economic growth in Bali is an effort made by the community in carrying out economic activities to meet the needs of life during the covid-19 pandemic.

Economic activity is an activity consisting of production, distribution and consumption activities as a human effort in the context of meeting needs. According to [5], Human existence cannot be separated from nature to try to maintain and maintain survival. Often the measurement of the welfare of human life is measured by the standard of economic satisfaction that can be achieved through these economic activities. Economic activities in Bali in terms of production activities in the field of art produce clothes, sculptures, paintings, kris, kites and so on. The art products are sold to domestic and foreign tourists who travel to Bali. In addition, Balinese art products are also often exported abroad according to the agreement between the exporter (Balinese entrepreneur) and the importer. Prior to the Covid-19 pandemic, usually exports to foreign countries were often carried out by art entrepreneurs in Bali, such as what was done by Mertasari Kite Shop.

Mertasari Kite Shop is one of the businesses that has artistic products in the form of kites. The shop is located at Br. Penida, Batuan Village, Gianyar Regency, Bali Province. The kite products are usually sold to local communities and exported abroad. The existence of the Covid-19 pandemic has made many businesses in Bali out of business because they immediately lost consumers drastically. Ideally a business must be able to make adaptations or adjustments according to the current situation or situation. This is a concern for entrepreneurs today to make one of the indicators in analyzing business feasibility. Based on the results of initial observations, it was found that there was an adaptation of economic activities carried out by Mertasari Kite Shop during the covid-19 pandemic, therefore the authors were interested in knowing this more deeply by conducting a study entitled "Adaptation of Mertasari Kite Shop's Economic Activities during the Covid-19 pandemic".

\section{METHOD}

This research method uses descriptive qualitative method. Qualitative method according to [6] are research that explores and understands the meaning in a number of individuals or groups of people originating from social problems. Qualitative research in general can be used in research related to people's lives, history, behavior, concepts or phenomena, social problems, and others which will be described descriptively. The subject of this research is Mertasari Kite Shop while the object is the adaptation of Mertasari Kite Shop's economic activities during the covid-19 pandemic. The technique used in collecting data in this study were observation and interviews with the owner of the Mertasari Kite Shop named I Wayan Suteja. According to Miles and Huberman in [7], the data that has been collected is analyzed through three stages, namely (1) data reduction, (2) data presentation, (3) drawing conclusions. Activities in reducing data are activities that summarize the outline of the data has been obtained so that the results of the research become clear. After that, the data is presented. The data is then presented in the form of simple information related to the description of the adaptation of economic activities carried out by Mertasari Kite Shop during the covid-19 pandemic. The last is drawing conclusions to make it easier to know the outline of the research results.

\section{RESULTS \& DISCUSSION}

Mertasari Kite Shop was founded by I Wayan Suteja. This business was started in 2011, whose main location is in Br. Lodsema, Lotunduh Village, Gianyar Regency Bali and its shop in Br. Penida, Batuan Village, Gianyar Regency, Bali Province. Based on the results of the interview, I Wayan Suteja said that:

"Mertasari Kite Shop was inspired by the late Mr. Made Budiasa who was the owner of Jaya Sairam and also from Balinese culture who has always played kites".

I Wayan Suteja has been making kites since 2000 since he was in high school and started the Mertasari Kite Shop business while working as a guide at a travel agent. 
Mertasari Kite Shop produces kites that are easy to fly and easy to carry as souvenirs for local and foreign tourists. An example of the products in Figure 1 is as follows.
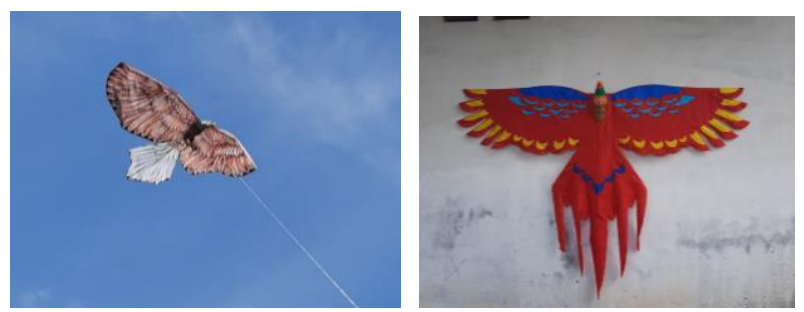

Figure 1. Kites

They sold kites of eagles, owls, dragons, bats, bean, butterflies, dragonflies and peacocks from $90 \mathrm{~cm}$ to $5 \mathrm{~m}$ in size. The selling price also varies from IDR $35,000.00$ to IDR 3,000,000.00. However, during the Covid-19 pandemic, Mertasari Kite Shop experienced changes in economic activities in order to adapt to the situation in the surrounding environment.

Adaptation of economic activities is carried out in order to maintain the business so that it continues to run as expected. Based on the results of observations and interviews, researchers got the results that the economic activities carried out by Mertasari Kite Shop before the covid-19 pandemic were producing according to orders and making stock of goods because every day there must be sales. The product sold to local people, to souvenir sellers at the Ubud market, to the Kuta art market, to the island of Java, to America, Australia, France, Germany and to tourists who directly come to the Mertasari Kite Shop

Since the covid-19 pandemic, Mertasari Kite Shop's sales to tourists have fallen drastically to almost zero. Therefore, Mertasari Kite Shop's economic activities after the covid-19 pandemic underwent significant changes. This adaptation is carried out to keep the business running during the pandemic. The statement from I Wayan Suteja said that:

"During the pandemic, sales to the domestic community increased somewhat during the kite season from May to September and also sales to the island of Java were quite good because people in Java really liked kites from Bali."

Based on this, Mertasari Kite Shop is trying to adapt economic activities during the covid-19 pandemic. The forms of adaptation of economic activities are as follows.

\subsection{Production Activities}

Production activity is an activity to produce a product or service, which is more clearly an activity to add value to an item. Mertasari Kite Shop adaptations in production activities are:

\subsubsection{Creating a New Design}

The new design gives a new impression on life in the era of new habits (new normal). This is done so that the image of Mertasari Kite Shop products is fresher to look at. So that it can attract consumer interest. This new design relates to the pattern or color on each kite that will be produced. Adaptation in this case is needed during the pandemic so that the resulting product gives a new and different impression from before.

\subsubsection{Product Diversification}

Product diversification is the diversification of production. Mertasari Kite Shop starting in early 2021 makes Hindu religious ceremony facilities for sale. Based on the results of interviews, the products that have been produced include umbul-umbul, wastra and tedung. Now it's still in the process to be better known in the surrounding community. An example of a product diversification is as follows.

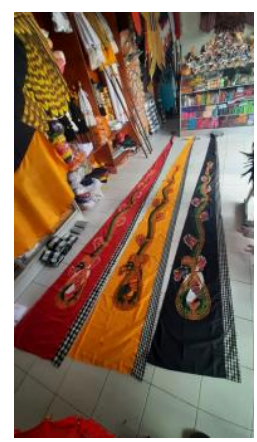

Figure 2. Umbul-umbul

\subsection{Distribution Activities}

Distribution activities are one of the economic activities that distribute or inform the products to consumers. Mertasari Kite Shop adaptations in distribution activities are:

\subsubsection{Maximizing Local Sales}

Prior to the covid-19 pandemic, Mertasari Kite Shop's sales target was local people and foreign tourists, but there was an adjustment to the main target during the covid-19 pandemic, namely local communities. These local communities include the people of Bali, Java or all of Indonesia (domestic). With this adaptation, Mertasari Kite Shop tries to provide excellent service in the form of maximizing sales according to the kite season (when there is wind to fly the kite) besides that before the kite is sent to the customer, the kite has been tested for feasibility first so as to provide satisfaction to local customers. 


\subsubsection{Promotion}

Adaptation in product introduction began to be carried out consistently during the pandemic, Promotions carried out by Mertasari Kite Shop through market places or social media so that the products produced could be known by the public. This is in line with [8] that the use of technology has become a necessity, improving online services for UMKM and the informal sector of the tourism industry is very important, for promotion, communication, the process of selling goods/services, such as through marketplaces and websites/applications. In addition, the right way in adapting UMKM actors according to [9] during this pandemic, namely doing online marketing, apart from opening a shop, you can also sell online during the covid-19 pandemic so that it can help reduce the spread of the covid-19 virus.

\subsection{Consumption Activities}

Consumption activities in producer households are in the form of the use of production factors. Mertasari Kite Shop's adaptation in production activities is the limitation of employee working hours. During the covid-19 pandemic, employees at Mertasari Kite Shop have reduced working hours. Employees work three times a week to reduce production costs.

Based on the adaptation of these economic activities, Mertasari Kite Shop can still survive during the pandemic. In addition, support from the local community is also needed to share information related to the products sold by Mertasari Kite Shop so that they are increasingly known. It is supported by [10] which states that the support of the surrounding community and local communities for tourism progress is very necessary, especially support through customary, village, and Banjar regulations that support and facilitate tourism development by strengthening and not eliminating Balinese local wisdom. The community needs to disseminate information and socialize so that the products or works of the Balinese people are known by tourists.

\section{CONCLUSION}

The existence of the covid-19 pandemic starting from 2020 until now has made every level of society adapt in their economic activities. In addition to the community, every company is also trying to adapt to maintain its company during this pandemic. Moreover, the orientation of their activities depends on the tourism sector, they make more adjustments so that the products they produce are sold. One of them is Mertasari Kite Shop making adaptations in its economic activities such as in (1) production activities: creating new designs, product diversification, (2) distribution activities: maximizing product sales, promotions and (3) consumption activities: limiting employee working hours. Based on this adaptation effort, it is hoped that the Mertasari Kite Shop business will continue to survive during the covid-19 pandemic.

\section{AUTHORS' CONTRIBUTIONS}

Suggestions from researchers for future researchers are to try to find adaptations of economic activities during the pandemic that are carried out by other sectors besides the tourism sector so that they are able to provide references to readers to practice in everyday life.

\section{ACKNOWLEDGMENTS}

Thank you to the owner of Mertasari Kite Shop for taking the time to be interviewed. I wish you more success.

\section{REFERENCES}

[1] P. S. Jayendra and K. A. Ekasani, "Pandemi Covid-19: Momentum Introspeksi Tatanan Kehidupan Beragama Dalam Stagnasi Pariwisata," in Buku Pariwisata Covid, 2021, pp. 29-36.

[2] I. A. D. Arini, I. B. G. Paramita, and K. A. Triana, "Ekspektasi, Realisasi Dan Negosiasi Tourism Reborn Di Masa Pandemi Dalam Pariwisata Bali," CULTOURE Cult. Tour. Relig., vol. 1, no. 2, pp. 101-112, 2020, [Online]. Available: https://scholar.google.co.id/citations?view_op=v iew_citation\&hl=en\&user=2YjkOLUAAAAJ\& citation_for_view=2YjkOLUAAAAJ:ux6o8ySG0sC.

[3] I. G. G. P. A. P. Ida Bagus Gede Paramita, "New Normal Bagi Pariwisata Bali Di Masa Pandemi Covid-19," J. Ilm. Pariwisata Agama dan Budaya, vol. EISSN 2614, p. ISSN 2527 9734, 2020, doi: 10.36275/mws.

[4] bi.go.id, "Laporan Perekonomian Provinsi Bali," 2021 https://www.bi.go.id/id/publikasi/laporan/lpp/Pa ges/Laporan-Perekonomian-Provinsi-BaliFebruari-2021.aspx.

[5] I. Dwina, "Melemahnya Ekonomi Indonesia Akibat Covid-19," Cent. Open Sci., pp. 1-5, 2020, doi: 10.31219/osf.io/8e27t.

[6] J. W. Creswell, Research design: pendelatakan Metode kualitatif, kuantitatif dan Campuran. Yogyakarta: Pustaka pelajar, 2016.

[7] Sugiyono, Metode Penelitian Kuantitatif, Kualitatif, dan $R$ \& D. Alfabeta, 2016.

[8] Badan Pusat Statistik Jawa Barat, Analisis Isu 
Terkini Provinsi Jawa Barat 2020. BPS Jawa Barat, 2020.

[9] W. Barisa, "Adaptasi Usaha Mikro Kecil Menegah (Umkm) Dimasa Pademi Covid-19," Publicio J. Ilm. Polit. Kebijak. dan Sos., vol. 3, no. 1, pp. 40-44, 2021, doi: 10.51747/publicio.v3i1.660.
[10] I. W. Sugita and I. M. B. Wisnawa, "Strategi Pengembangan Pariwisata Bali Menghadapi Pandemi Covid-19 Melalui Peran Asosiasi Profesi," J. Manaj. Pelayanan Hotel Akad. Komunitas Manaj. Perhotelan Indones., vol. 5, no. 1, pp. 30-50, 2021. 